\title{
Can we make participatory NTFP monitoring work? Lessons learnt from the development of a multi- stakeholder system in Northern Laos
}

\author{
M. Boissière • F. Bastide • I. Basuki · J. L. Pfund • A. Boucard
}

Received: 6 December 2011/Accepted: 5 November 2013/Published online: 20 November 2013

(C) The Author(s) 2013. This article is published with open access at Springerlink.com

\begin{abstract}
Monitoring natural resources is essential for their successful and sustainable management. Community participation should enable local people to take ownership of the monitoring and ensure that it is cost-effective. But even then, success is often elusive. We developed a participatory Non Timber Forest Product (NTFP) monitoring system in 6 upland villages of Luang Prabang Province, Lao PDR, using focus group discussions, interviews, village meetings and direct observations. We used simple approaches to select resources, discuss issues, and develop a cost-effective NTFP monitoring system. Communities usually relied on shifting cultivation, fishing and collection of NTFPs. Gold mining activities affected livelihoods in three villages, which had better access to markets. Participatory monitoring looks less successful when external economic pressures or a major environmental threat disturbs local livelihoods. In the case of gold mining, we observed the prioritization of villagers' activities towards this sudden new economic opportunity. In contrast, communities not impacted by mining participated more actively in data collection. They understood how the data could be used to influence the local government, to achieve more beneficial land management for all stakeholders concerned. We believe that participatory NTFP monitoring can work and is an important tool for decision-making and economic empowerment for local communities. We identified the conditions under which participatory NTFP monitoring could work: reaching a shared understanding of what needs to be monitored and how; testing and refining a simple monitoring system; and integrating local government concerns with those of other stakeholders.
\end{abstract}

\footnotetext{
M. Boissière $(\square)$

Centre de Coopération Internationale en Recherche Agronomique pour le Développement (CIRAD), Campus de Baillarguet, 34398 Montpellier Cedex 5, France

e-mail: m.boissiere@cgiar.org

M. Boissière · F. Bastide · I. Basuki · J. L. Pfund · A. Boucard

Center for International Forestry Research (CIFOR), Jalan CIFOR, Situ Gede, Sindang Barang, Bogor 16115, Indonesia
} 
Keywords Participatory monitoring system $\cdot$ NTFP $\cdot$ Multi-stakeholders $\cdot$ Adaptive management · Lao PDR

\section{Introduction}

Monitoring is the systematic gathering and analysis of information to observe change in the physical and social environment (Evans and Guariguata 2007; Garcia and Lescuyer 2008). In the area of land management, participation in monitoring requires the involvement of different stakeholders: local communities, decision-makers, scientists and NGOs. Its function as a "cornerstone to effective decision-making in natural resource management" makes it a powerful tool for adaptive co-management (Cundill and Fabricius 2009). It promotes social learning and collaboration in environmental management. It is not only considered a cost-effective tool (Danielsen et al. 2005a; Sheil and Lawrence 2004), but also a means to allow feedback for land management (Armitage et al. 2009; Berkes and Folke 1998; Berkes et al. 2000; Stringer et al. 2006).

Most studies on participatory monitoring are site-oriented, which makes them descriptive and anecdotal, and it is therefore difficult to extract general guidelines applicable to different scales and situations. Few attempts have been made to link different studies to a theoretical framework. Some authors have only proposed a characterization of monitoring approaches according to the degree to which local communities are engaged in data gathering and analysis (Danielsen et al. 2008; Evans and Guariguata 2007).

Many case studies show the value, success and interest of land users in the participatory monitoring approach (Andrianandrasana et al. 2005; Danielsen et al. 2005b; Noss et al. 2005; Rijsoort and Jinfeng 2005). They also argue the need to promote the local point of view and participation in decision-making (Danielsen et al. 2005a).

A few authors have underlined the limitations and caveats related to participatory monitoring and suggested ways to address them (Garcia and Lescuyer 2008; Poulsen and Luanglath 2005; Webber et al. 2007; Yasue et al. 2010). They highlight the difficulty in scaling up the results for natural resource management decisions. Local people do not always understand the concept of monitoring, and by extension, the benefits they could receive. Lack of incentives to follow up for long periods and time limitations make monitoring difficult to sustain. According to these authors, developing a comprehensive framework of long-term participatory monitoring, ensuring local interest, and offering incentives are key issues to be addressed.

We agree that incorporating local needs and opinions in all aspects of natural resource management, including monitoring, is a prerequisite for success. In the hope of making local participation more successful and sustainable, we developed a multi-stakeholders' monitoring system of natural resources, in 6 villages in Northern Laos. We focused on simple tools to assess the availability of important Non Timber Forest Products (NTFPs), rather than focusing on biodiversity, a hard to define concept. The originality of our approach was that it linked governance structures, important natural resources for various stakeholders, including local communities and government staff at the district level, and a new policy, Participatory Land Use Planning (PLUP). The latter was intended as a way to give more voice to local people in land management. We also aimed at understanding the conditions for participatory monitoring to work, taking into account different characteristics such as the distance to market or the presence of roads and other infrastructure. 
In this paper we examine the step-by-step approach we used to develop NTFP monitoring with local community and government staff participation. We provide an example of participatory approaches to integrate different perspectives (e.g. villagers, district officers and conservation organizations). Then we discuss issues of participation and sustainability. Finally, we propose a monitoring system that could be easily integrated into local governance and government policies, followed by a discussion on the potential and limitations of the approach.

\section{Research context and site description}

\section{Research context}

Between 2009 and 2010, research on participatory biodiversity and livelihood monitoring was conducted in Laos as part of a broader study on the links between livelihoods and biodiversity values in fragmented landscapes (CIFOR 2010; Laumonier et al. 2008; Pfund et al. 2011; Belcher et al. 2013). These landscapes are facing rapid changes, with new economic developments (e.g. increasing numbers of investors and companies operating in this region, livestock improvement, tree planting, and an improved road network) (NAFRI, NAFES and NUoL 2005).

Other contributors to change in the landscape include government policies. In the late 1990s there was a move to halt poppy farming (UNODC 2005) followed by a policy to reduce poverty and to eradicate shifting cultivation through Land Use Planning (LUP). The resulting progressive rural transition from subsistence agriculture to market oriented crops has also contributed to changes in the landscape. These changes need to be monitored, notably their effects on the availability of subsistence and marketable products. To develop monitoring tools relevant to conservationists, local government and local communities, we need to ensure active participation at all levels, particularly of local elites. We also considered how our approach and results could be integrated into current government policies, especially those related to LUP, which are of growing importance in Laos.

\section{Site description}

Initially, we selected seven villages (one village was dropped from this activity because of its relocation during the project implementation ${ }^{1}$ ) as pilot sites according to: ethnicity, distance to a protected area [Nam Et-Phou Loei National Protected Area (NPA)], distance to market and infrastructure, altitude (from 500 to $1,000 \mathrm{~m}$ ), and population density (Table 1). The location of the seven villages shows a gradient of these various factors. All sites were located in Viengkham District (see Fig. 1), one of the poorest districts in Laos, but with the most forest in Luang Prabang Province. Forests near the villages were degraded and scattered in small patches in this hilly, mountainous landscape. Hmong, Khmu and Tai-Lao were the main ethnic groups in these villages (Chazee 1999; M. Roberts, personnal communication 2010).

Local livelihoods are mainly based on slash-and-burn cultivation of upland rice, irrigated rice fields (i.e. Muangmuay), fruit and vegetable gardens and livestock (e.g. cattle,

\footnotetext{
${ }^{1}$ Phadeng Village was moved further away from the NPA buffer zone and closer (according to the government resettlement strategy) to infrastructure and services (health and education). It was subsequently merged with another Hmong village (Phoukhong) located close to the road (Watts et al. 2010).
} 


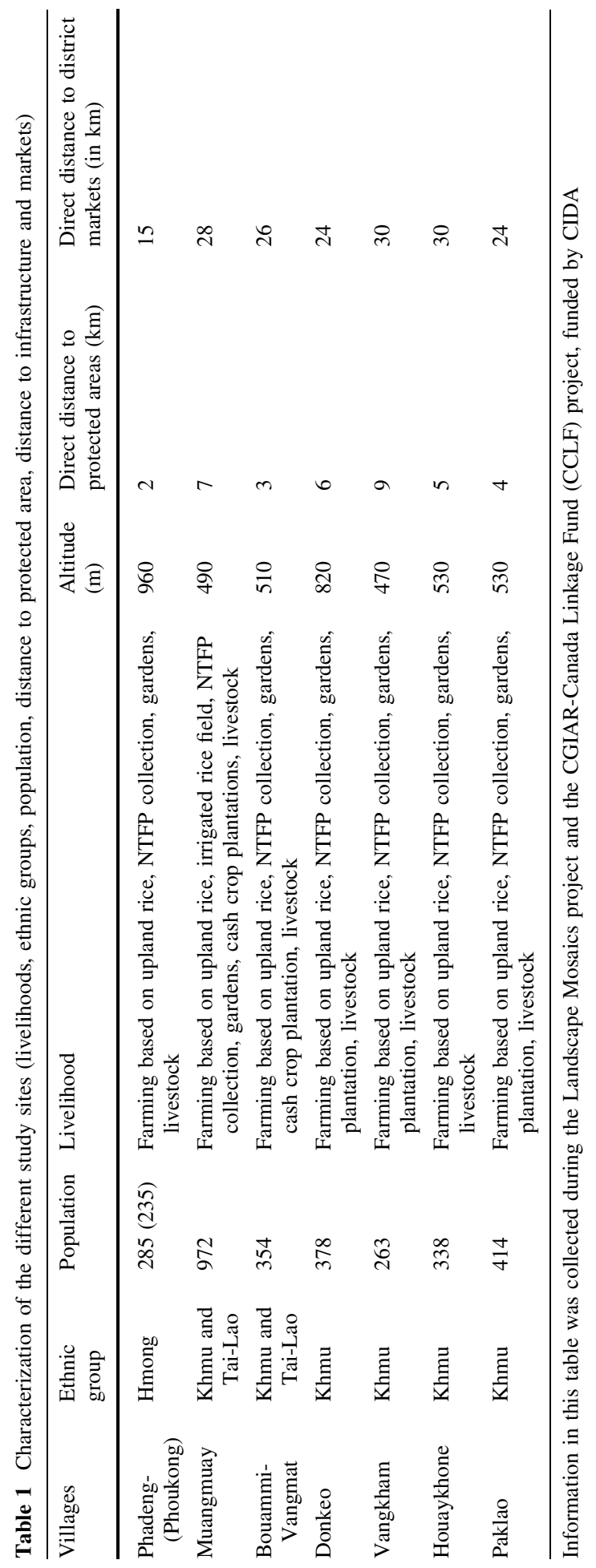




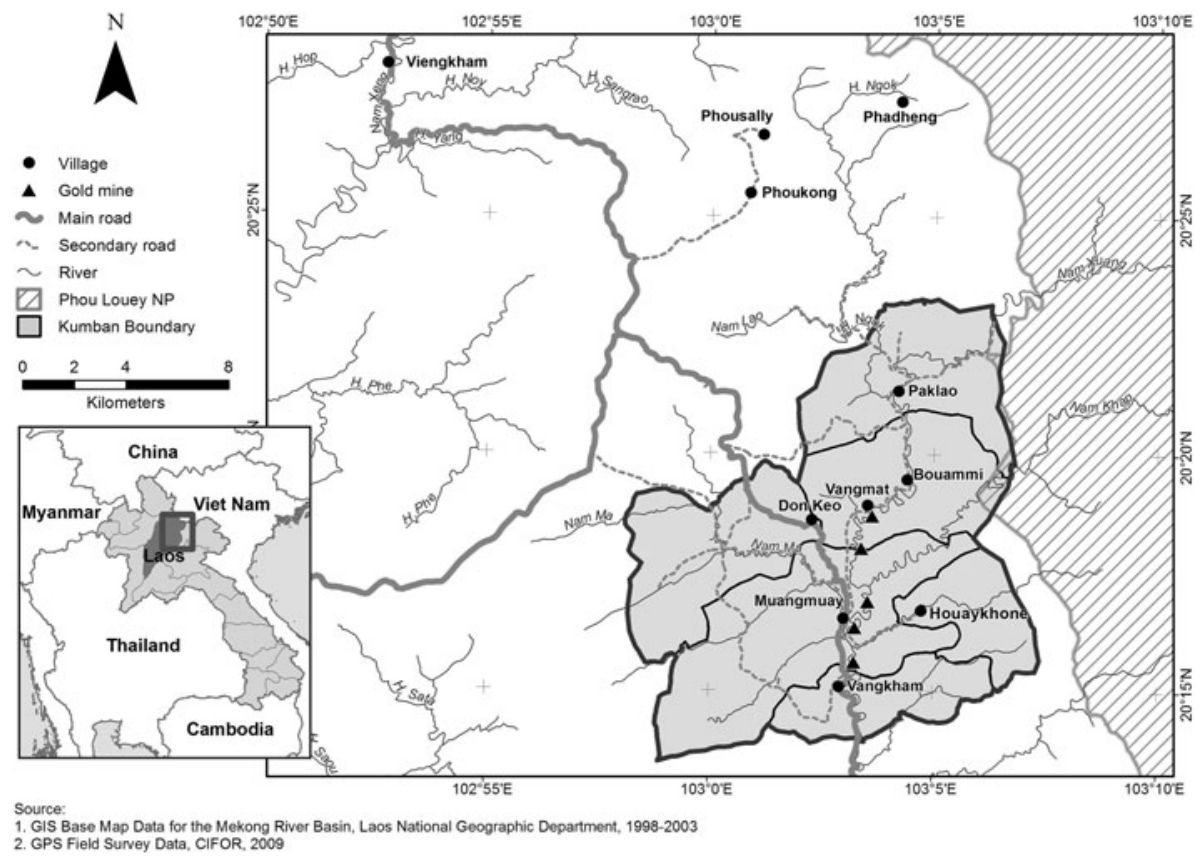

Fig. 1 Map of Muangmuay Village Cluster, District of Viengkham, Province of Luang Pabrang, Lao PDR

pigs, chickens). In order to eradicate shifting cultivation, the local government has supported villagers' efforts in planting cash crops such as teak (Tectona grandis), eaglewood (Aquilaria crassna) and rubber (Hevea brasiliensis). In some villages, fish is an important food and source of cash income (when the village is not far from a market).

NTFPs also play an important role in Viengkham's development. Countrywide, their commercial value may reach US\$ 7-8 million a year, reflecting the expanding small and medium-scale processing industries. It is estimated that in rural areas NTFPs, at the household level, are annually worth about US\$ 300 (NAFRI, NUOL, SNV 2007).

In Viengkham, dependency on forest products varied according to the villages' location. Some of the most valuable NTFPs have been domesticated or are in a process of domestication, for example, pigeon pea (Cajanus cajan), broomgrass (Thysanolaema maxima), peuak meuak (Boehmeria malabarica), and paper mulberry (Broussonetia papyrifera) (Weyerhaeuser et al. 2010). NTFP domestication tends to occur in villages located far from valuable forest resources or where tenure improves the resource security. The local government has also provided NTFP seedlings and training through a decentralized technical organization called Technical Service Center (TSC), located at the village cluster level.

\section{Village cluster}

The six villages were part of the same village cluster, or kumban pattana (Fig. 1; Table 1). The kumban has been a priority for the Lao administration since 2004. As an institutional link between the district and village levels, it is: 
A formal administrative grouping of villages within a district defined for the purpose of extending government policies and development programmes (MAF and NLMA 2010)

Their focus is on agricultural extension, LUP, reporting to the district, and implementing and monitoring land management (Foppes 2008; Prime Minister 2008). A key institution within the kumban, TSC is in charge of the agricultural and forestry extension and management. Its roles are:

To extend and transfer production techniques, lead farmers to produce and provide information (MAF 2008)

We used the kumban as a knowledge platform. Because the TSC acts as a disseminator for the district, the kumban is an ideal space to promote stakeholder participation in monitoring.

\section{Methods}

Methods used for selecting the resources to be monitored, choosing indicators, developing the monitoring tools, and building local capacity to use them, were partially adapted from multidisciplinary approaches. The latter were developed to understand and assess local perceptions of land features and natural resources (more in Sheil et al. 2002).

\section{Community meetings}

Community meetings, with an average of 30 attendants in each village, were held through regular and repetitive village visits. In the meetings we presented our research purpose, assessed local interest, and asked for villagers' participation, then later validated our findings (e.g. for the selected NTFPs to monitor, the monitoring tools to be used with villagers and how to report). Community meetings were used for interactive explanation of monitoring concepts and goals. Short dramatic performances were used to explain the concepts (DeNeve and Heppner 1997). These plays featured three members of our team simulating situations, in which natural resource management, market(s), and negotiations with the authorities benefit from monitoring (Boucard et al. 2010).

During the community meetings, we tried to keep a gender balance, so that women, who play a major role in NTFP harvesting and trade, could express their concerns and wishes. To do so, we used the "talking stick" method (Colfer 2007). The speakers passed a small bamboo stick to each other to use like a microphone. We had men or women assisting in the meetings, especially with the people who where usually quiet. Attendance for these meetings varied among villages and according to the season and villagers' free time.

\section{Participatory mapping}

The objective of mapping was first to build a common understanding between villagers and scientists on the locations of natural resources and their importance; and second, to understand how villagers spatially used their land and resources (Sheil et al. 2002). Maps were developed by 5 groups [women and men (young and old), and one group of village officials], and then merged. Each group was provided with a base map showing the rivers, village location, and roads based on a SPOT 5 satellite image (30 Meter Digital Elevation Model, acquired on March 1,2007). These separate groups were important to compare their varied 
knowledge and to provoke discussion. Producing these maps required good facilitation to avoid influencing the process and to give each group a chance to provide its own version (Chambers 2006). An example of these maps is provided in Fig. 2, for Muangmuay village. Another example focuses only on the selected NTFPs, with their toponyms (Hargitai 2006), and was part of the testing of the monitoring approach (Fig. 3). The development of the maps with villagers was then followed by ground checks, using GPS, to verify the position of rivers, hamlets and other important features with the help of local guides.

\section{Scoring exercises}

Scoring exercises were used to select the most important forest products according to the same groups of villagers involved in the mapping exercise. These scoring activities were also used to assess the importance of forest in the past, present and future from a local point of view and to understand the evolution of local perceptions (Sheil et al. 2002). One hundred counters were distributed to each group, who divided them between the different resources or land types to indicate their relative importance.

Focus group discussions

Focus group discussions (FGD) were used to answer semi directive questionnaires on location and local management of important NTFPs, and markets. These exercises also used five groups as in the mapping exercises, but with different participants. We limited the number of participants to five or six persons per group. A facilitator made sure all participants had a chance to express themselves.

Village level interviews and household surveys

Once the NTFPs to be monitored were identified, household surveys were conducted to locate the main area where each household collected NTFPs, the amount collected per year, and what income these generated. At least 25 households were surveyed in each village. Resource persons (e.g. hunters or specialists in the collection of one specific product) were also interviewed on harvesting/hunting techniques.

\section{Results: Participatory monitoring in the making}

For the development of the monitoring tool, we identified, with the participation of multiple stakeholders, key resources and indicators to be monitored. This included ways to conduct the monitoring. We also deliberately integrated this resource monitoring into a local governance mechanism and we looked for long-term use of the monitoring system by proposing that it be embedded into a key land management policy, here LUP.

Development of the multi-stakeholders' monitoring system

\section{Selection of key resources}

We built a monitoring tool based on the local viewpoint. During FGD we prepared a list of the most important NTFPs used by villagers, for trade or their daily needs (e.g. for 


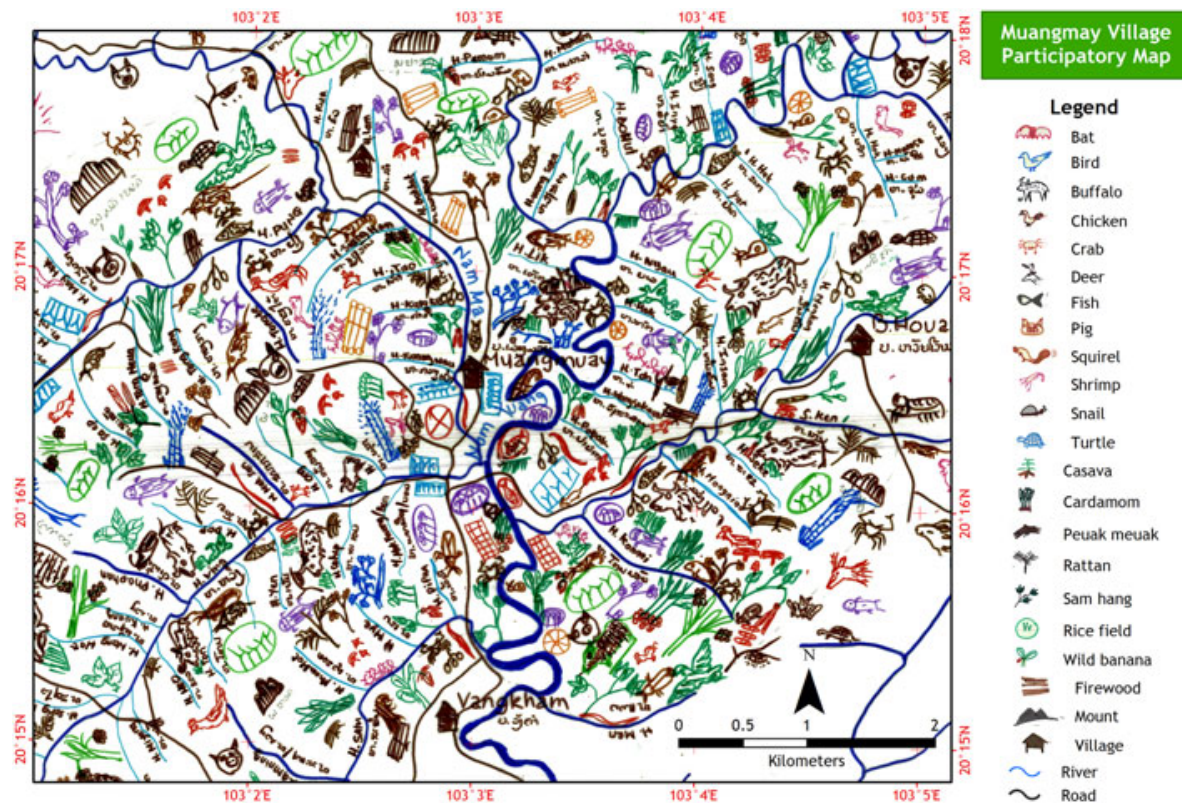

Fig. 2 Participatory map of natural resources and important land types according to five groups of villagers in Muangmuay [women and men (old and young), and village officials]

construction materials, food and hunting; Boucard et al. 2010). In each of the pilot sites we produced a list of a hundred plants and animals, using scoring exercises. We then reduced the list to the 20 most important natural resources for each village. This was key to create a list of resources considered as important by the villagers present during these discussions.

We then analysed the 20 natural resources based on criteria that took into account both conservation and development priorities, according to local government and NGOs. Resources important for conservation were wildlife found in the NPA and economic resources were marketable NTFPs found near the village. More scientific criteria such as the multi functionality of the chosen species (Table 2) were also considered. We scored each of these species according to the criteria. We kept the 6 species with the highest scores for the combined criteria. Villagers, during a community meeting, selected 3-5 species (Table 3). Facilitators made sure every group was represented and contributed to the selection. During the community meetings, villagers adapted and sometimes partly changed the list of resources to be monitored, according to new priorities (e.g. new market potential or recent domestication).

The final list of resources to be monitored was based on the interests of both communities and government agencies, even though interests and priorities could change over time. Discussions and rating exercises were also conducted with representatives from the District Department of Forestry. Among the criteria we used was villagers' dependence on products for subsistence (e.g. fish and bamboo shoots) and trade (e.g. peuak meuak, paper mulberry, and broom grass). We confirmed the importance of each product, their distribution within each village's territory, and their contribution to each household's income, using household surveys and key informant interviews. Figure 3 shows a map of the main selected NTFPs at the village cluster level (kumban). 


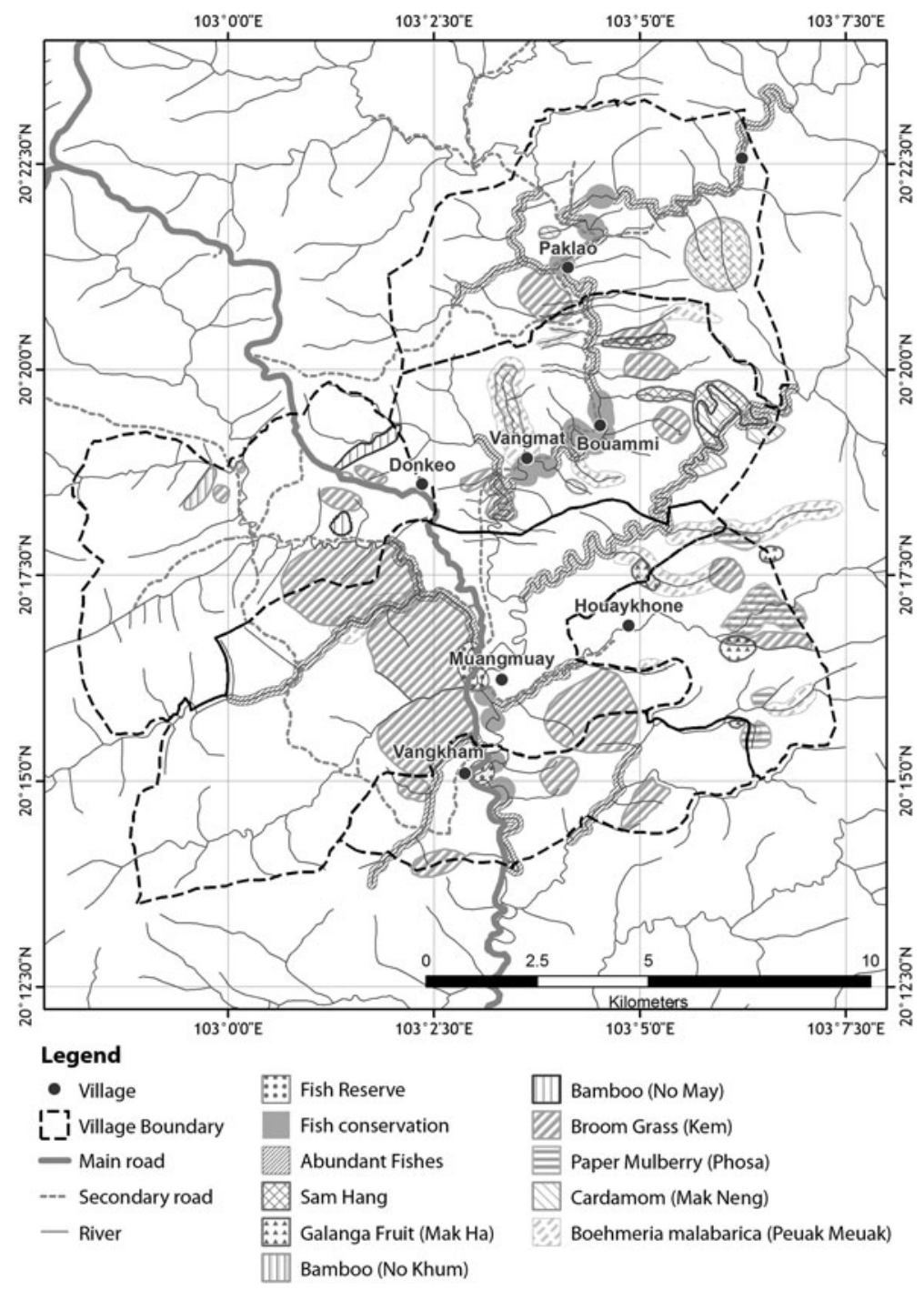

Fig. 3 Map of the main selected NTPFs in Muangmuay village at cluster level according to a group of collectors

\section{Resource monitoring and management at the village level}

During further community meetings with the contribution of all interested stakeholders, including villagers, the Department of Forestry at the district level and TSC at the kumban level, we chose the best way to collect regular information on the monitored resources. We decided on the support required and the level of data collection in the village at the household level. Volunteers were responsible for noting their NTFP collection (quantity, location and total income), while the heads of village units (each village is divided in units, or clusters of households, and each unit is led by a villager) together with the village head, were in charge of aggregating the data and formulating recommendations for the kumban 


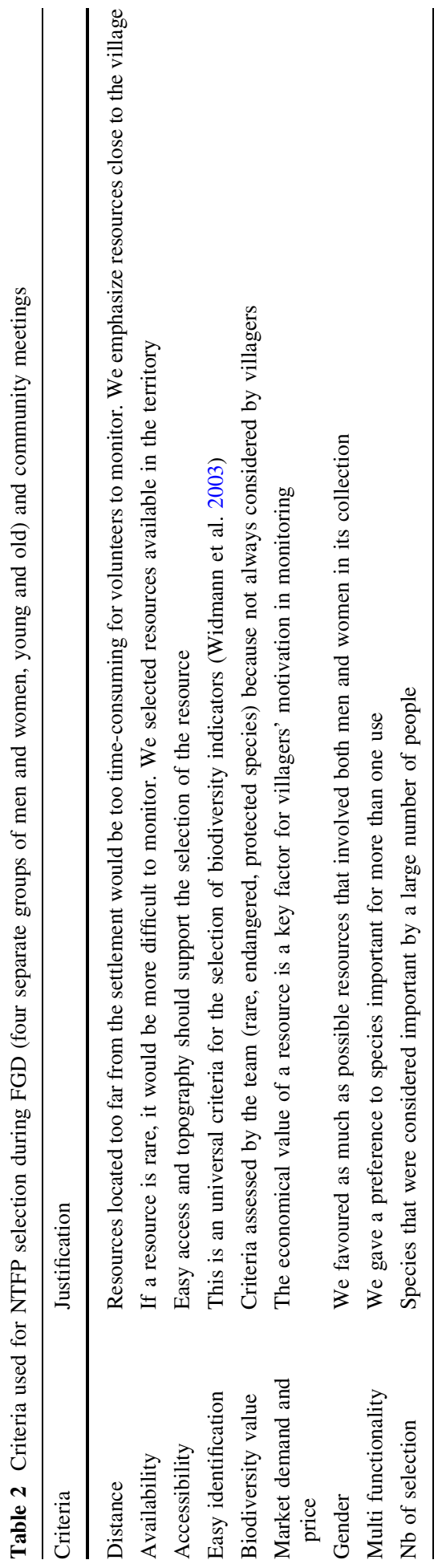


Table 3 Final list of selected NTFPs for the 6 villages of the village cluster

\begin{tabular}{|c|c|c|c|c|c|c|c|}
\hline \multirow[t]{2}{*}{ NTfPs } & \multicolumn{7}{|l|}{ Villages } \\
\hline & $\begin{array}{l}\text { Muang } \\
\text { Mouay }\end{array}$ & Bouammi & $\begin{array}{l}\text { Vang } \\
\text { Mat }\end{array}$ & $\begin{array}{l}\text { Houy } \\
\text { Khone }\end{array}$ & $\begin{array}{l}\text { Vang } \\
\text { Kham }\end{array}$ & Donkeo & Paklao \\
\hline$\frac{\text { Peuak Meuak }}{\text { Boehmeria malabarica }}$ & $\mathrm{X}$ & $\mathrm{X}$ & $\mathrm{X}$ & $\mathrm{X}$ & $\mathrm{X}$ & $\mathrm{X}$ & $\mathrm{X}$ \\
\hline $\begin{array}{l}\text { Broom grass } \\
\frac{\text { Kem }}{\text { Thysanolaema maxima }}\end{array}$ & $\mathrm{X}$ & $\mathrm{X}$ & $\mathrm{X}$ & $\mathrm{X}$ & $\mathrm{X}$ & $\mathrm{X}$ & $\mathrm{X}$ \\
\hline $\begin{array}{l}\text { Fish } \\
\text { Paa }\end{array}$ & $\mathrm{X}$ & $\mathrm{X}$ & $\mathrm{X}$ & & $\mathrm{X}$ & & $\mathrm{X}$ \\
\hline $\begin{array}{l}\text { Cardamom } \\
\text { Mak Naeng } \\
\text { Aтотит sp. }\end{array}$ & & $\mathrm{X}$ & $\mathrm{X}$ & & & & $\mathrm{X}$ \\
\hline $\begin{array}{l}\text { Bamboo shoot } \\
\text { No Hok } \\
\text { Dendrocalamus sp. }\end{array}$ & $\mathrm{X}$ & & & & & $\mathrm{X}$ & \\
\hline $\begin{array}{l}\text { Galangal } \\
\text { Kha } \\
\text { Alpinia galanga }\end{array}$ & & & & $\mathrm{X}$ & & & \\
\hline $\begin{array}{l}\text { Paper mulberry } \\
\text { Po Saa } \\
\text { Broussonetia } \\
\text { papyrifera }\end{array}$ & & & & $\mathrm{X}$ & & & \\
\hline$\frac{\text { Sam Muang }}{\text { Flemingia latifolia }}$ & & $\mathrm{X}$ & & & & & \\
\hline $\begin{array}{l}\text { Bitter bamboo shoot } \\
\text { No Khum }\end{array}$ & & & & & & $\mathrm{X}$ & \\
\hline
\end{tabular}

Bold: English; Underline: Lao; Italics: Latin

authorities. The village head was responsible for reporting to the kumban. It was agreed that each participating household should use logbooks. They would record the amount of NTFP collected every day. We did not distribute pre-prepared logbooks, but rather empty schoolbooks, broadly available in village shops, to reduce costs and prevent dependency on an external source of predesigned logbooks. During several training sessions, we taught villagers how to prepare and fill in data. Once a month, a team visited each of the research sites to check the books and help the villagers who had difficulties entering the data. The exercise was not totally new especially for the village authorities, which have to regularly report to the district authorities on crop production, plantation area, and number of cattle in the village. Equally, the villagers did not want a simple model using shapes rather than words, as this would give an impression of illiteracy. The team also provided training on how to use the collected data, i.e. how to create bar and line charts to visualise the evolution of the resources from tables.

As long as the activities were about selection and monitoring methods of NTFPs, villagers' participation was ensured in most of the villages, especially the most isolated ones (i.e. Bouammi-Vangmat, Houaykhone, Paklao). It was, however, more difficult for villagers located close to the road to participate as they were engaged in more diverse market oriented activities and had less time available. In Muangmuay, the main village of 
the kumban, this was especially true. When we visited for follow-up meetings after a month, we found the level of delegation higher in Muangmuay than in the other villages. Household members who agreed to fill-in logbooks with the harvest of selected NTFPs would delegate to some other household members the presentation of the monthly results during community meetings.

Local understanding of the monitoring system and its effect on natural resource management

\section{Local people's perceptions of the monitoring system}

The villagers could see the monitoring system as a way to follow the evolution of important resources and as a tool for linking local NTFP management at the village level to decision-making at the district level.

For example, monitoring could provide information on endangered forest products, which deserved protection measures. Bamboo shoots were considered endangered by villagers from Vangkham village. A village-agreement led to a temporary suspension of its collection. Villagers could then inform the district about their management practices during the regular village head's report to the district authorities.

\section{Contribution of local knowledge to the NTFP monitoring system}

We observed existing resource management and control at the village level in Muangmuay and Bouammi-Vangmat where fish reserves were created in 2000 (see Fig. 3). This fish stock can be harvested prudently for important occasions (e.g. festivities, marriages) and only outside the breeding season. Villagers also forbid the use of blast fishing or electrofishing. Another example is peuak meuak, which was selected by all the pilot villages because of its importance for trade (the bark is used for glue and incense). This plant grows in humid soils on riverbanks. Its harvest, in which both men and women are involved, is recognized by villagers to be unsustainable, because of the absence of management rules and the collection of the plant's roots. Villagers expected the monitoring activities to help them refine harvesting regulations for natural resources (such as fishing) and provide numbers on trends and cash income for discussion within the village.

Villagers saw the monitoring tool as an instrument with potential for natural resource management, but also as a distraction from their daily activities, and not providing any direct income to the households. As long as it didn't interfere with their normal activities, they participated willingly; otherwise they would be more careful about getting involved.

\section{Linking resource monitoring to multilevel governance}

Once the resources to be monitored and monitoring tools were chosen we discussed, with villagers, representatives from the district and from the kumban, about how to integrate the monitoring tools into the district land management and reporting system in a way relevant to all stakeholders. The decision was made to use the existing administrative structure, present at the district level, to avoid adding administrative complexity to the existing one and to facilitate the acceptance and ownership of the system from government stakeholders. The existing structure requires regular reports from households to the heads of village units, then to village heads, from village heads to kumban and then to the district 


\section{GOVERNANCE STRUCTURE}

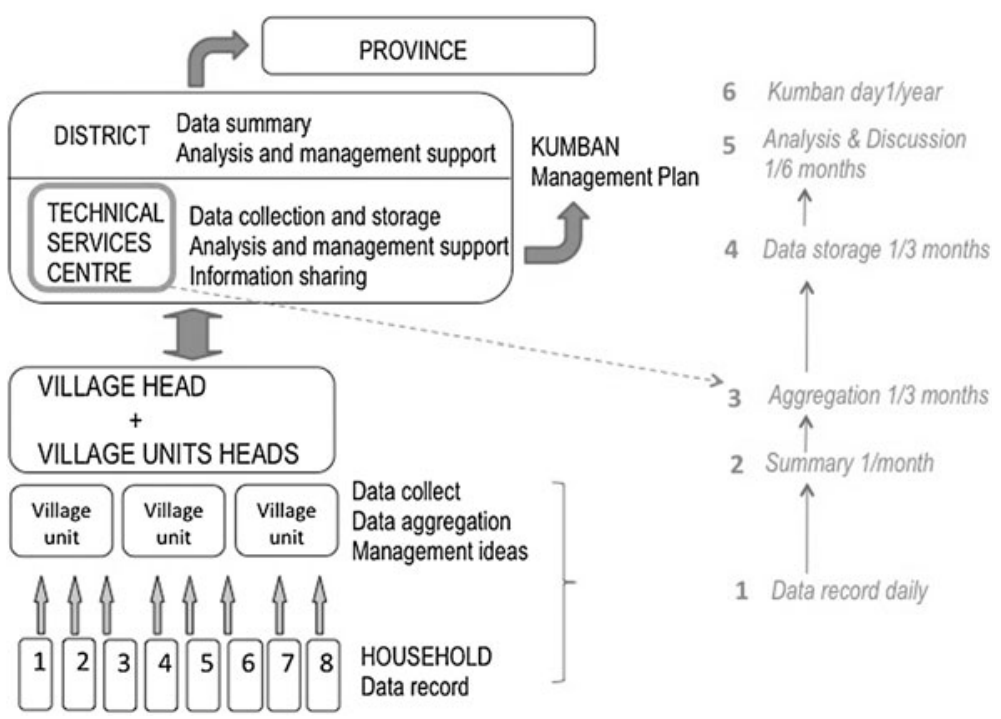

Fig. 4 The monitoring system as part of Viengkham District administrative structure. In black the administrative structure and in grey the proposed monitoring system

government. Figure 4 shows our proposal for incorporating the monitoring activities into the structure.

\section{Implementation tools for NTFP monitoring}

With the kumban being a new institution in Laos we had to decide what its role and functions in the monitoring system would be. Discussions with villagers, kumban representatives, and district authorities helped to identify three potential key roles of the kumban in monitoring in the future:

- Data collection and training: one of the recognised functions of the kumban, through its TSC, is to provide further forestry and agricultural techniques to improve local livelihoods. Its interest in collecting data related to key NTFPs harvested in the wild or domesticated makes it a key institution for regularly checking the logbooks with villagers, and collecting aggregated data.

- Data management and storage: villagers and district officers identified storage and utilization of information as an important issue. So far, there is no appropriate archiving of the data collected from villages, resulting in the loss of the villages' data for LUP. The kumban, an institution closer to the village level in which village representatives play a vital role, could be used for archiving information reported by villagers and facilitate data sharing with other users (e.g. development agencies at the district level).

- Reporting: the kumban has to report to the district authority. This represents a natural step in the sequence of aggregation, recommendations and reporting of the monitoring 
system. The villagers should receive feedback and a report on decisions made, based on their reports.

Figure 4 also shows the frequency and level at which the collection, aggregation and reporting was decided by each stakeholder. Regular data collection would be made at the household level, summarized monthly at the village unit level, providing a 3-month aggregation at the village head level, with inputs from the village units. The 3-month aggregation would feed into recommendations for the local government. Every 3 months the aggregated data would be stored in the kumban (through the TSC), to support the biannual analyses and discussions between district, kumban and villages. Once a year the results of these discussions would be made official and forwarded to the provincial level.

Looking for sustainability: integrating resource monitoring into the "Participatory Land Use Planning" national process

Once the monitoring system, including results and activities, is embedded into the local administrative structure it requires political support to power the system and provide sustainability. During the project's life we only proposed ways to embed the monitoring tools into existing administrative structures. However, we have not received information as to whether the villagers and kumban authorities have adopted the system or not.

The Government of Laos has, in the past, introduced different LUP policies to alleviate poverty, with some success (Lestrelin et al. 2011). The most recent one, the PLUP, is intended to give villagers a stronger role in the negotiation process of village boundaries, land zoning and land management (MAF and NLMA 2010). It also recognises the key role of the kumban in the LUP process, instead of the district as in previous LUP exercises.

With the new role given to local communities, in association with the kumban, there is more likelihood of the proposed participatory monitoring system being sustained. PLUP follows 9 steps (MAF and NLMA 2010): (1) preparation; (2) socio-economic, land and forest data collection; (3) delineation of village and village cluster boundaries; (4) village and village cluster forest and agricultural land use zoning; (5) village and village cluster land management plans; (6) land data record keeping and digital mapping; (7) land registration and titling in rural villages; (8) village and village cluster networks and networking; and (9) monitoring and evaluation.

The villages of a kumban and the district authorities together designate the various zones as part of PLUP (step 4). The zones are the areas devoted to protection, conservation, economic activities (plantation and agriculture), infrastructure (village development) etc. They then produce a 5-year management plan for each zone.

PLUP in Muangmuay Kumban had not reached the monitoring step (step 9) by the end of the project (December 2010); it had only been implemented up to step 6 (more about the PLUP process in Bourgoin and Castella 2011; Bourgoin et al. 2012; Lestrelin et al. 2011). However, we were still able to discuss how PLUP could utilize the proposed monitoring system (Table 4). The system can be used as a tool to assess the impact of management decisions on local livelihoods (poverty) and natural habitats (biodiversity), based on the zones proposed within PLUP (e.g. residential areas, conservation forest, sacred forest, agriculture zone). However, time was lacking to ensure the formal integration of the participatory monitoring system into PLUP, which was still in the implementation process.

PLUP needs to predict and take into account events that could disrupt both planning and monitoring activities. This became evident during the testing of our methods, which were disrupted severely by gold mining. 


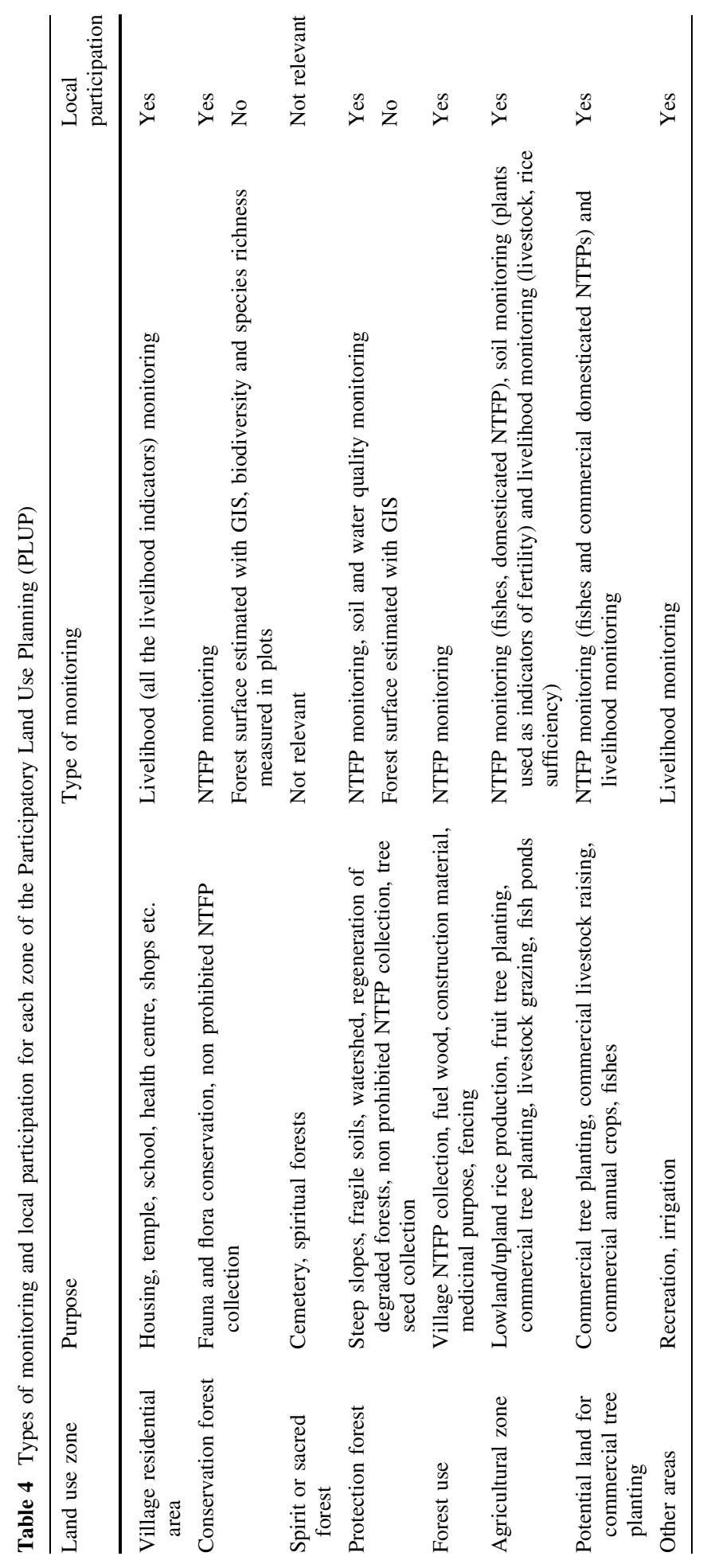


Limitations to the development of an effective natural resource monitoring

In 2010-2011, gold mining in the Nam Xuang River severely affected Muangmuay Kumban; the river's ecosystem was destroyed leaving villagers downstream without any fish resources. Official gold exploitation started in November 2010, giving rise to a rapid, uncontrolled spread of registered and unofficial miners. In July 2011, the local government put a stop to all gold mining in the area (Vilaphong, personal communication, 2013). The gold mining happened at a time PLUP was still under discussion and different steps had not been implemented in the kumban. The district authorities did not have the legal planning tool to prevent the uncontrolled mining and damage to the environment. There was also a clear lack of coordination between the district and provincial authorities on the issuing of mining concessions and villagers were not part of any negotiation. All but two of our target villages (Donkeo and Houaykhone) were affected by gold mining. In Bouammi and Paklao, small unofficial gold companies began to extract, but stopped because of threats of district sanctions. The most affected villages were Muangmuay, Vangkham and Vangmat (a subdivision of Bouammi village ${ }^{2}$ ). Between April and July 2010 the official company produced up to $7 \mathrm{~kg}$ of gold. The villagers were equally interested in gold extraction. Between July and September 2010, 30 villagers from Muangmuay invested in a villagebased gold concession. According to villagers, in little more than 4 months, the village production reached almost $1 \mathrm{~kg}$ of gold. But the most vulnerable families were worried about food resources particularly fish and other water resources (i.e. river algae, crabs, shrimp, molluscs). The official company confirmed the villagers' fears that it would not be possible to harvest such resources for several years after the mining finished.

\section{Discussion}

To achieve collaborative monitoring, it is important to reach a shared understanding among the different stakeholders, especially decision makers (in our case district authorities) and natural resource managers at the village level, of what needs to be monitored. Of equal importance is how to test and refine the monitoring system and embed it into the local governance, taking into account all stakeholders' concerns and practical choices.

\section{Participatory monitoring as a negotiation tool}

Communities are rarely in a position strong enough to negotiate with decision-makers under pressure from the private sector, especially in Laos, where top-down governance is combined with the economic interests of neighbouring countries looking for land (i.e. Thailand, Vietnam, and China) (Baird 2010). The example of the gold mining illustrates well the impact of new commercial activities and the limited capacity and power of the local people to react to the transformation of the landscape around their villages. Villagers living in close proximity to the gold mining were in fact more interested in short-term benefits through small-scale gold extraction than worried about long-term impacts on their

\footnotetext{
${ }^{2}$ The former village of Vangmat was merged with its neighbouring village, Bouammi, following a recent government policy for village stabilisation aimed to group small villages into bigger units. However, Vangmat remains physically separated from Bouammi (located $30 \mathrm{~min}$ walk from each other), each with its own territory. We therefore separated these two settlements.
} 
important NTFPs. Villagers not directly involved in the mining activity were more aware of its impact on the river conditions and their main source of food and livelihoods.

At the time of the gold mining activities, however, PLUP had not been entirely implemented in Muangmuay kumban. We believe that its full implementation would have enhanced local people's capacity for negotiation, and level of understanding of environmental risks and impacts.

A system that takes into account local governance and reflects all stakeholders' concerns

In the past, local perceptions were rarely taken into account when dealing with natural resource management (Fraser et al. 2006). In Laos, until 2011, the priority was generally given to what was considered important by the district authorities and conservation institutions. Government authorities still consider 'informing' villagers about the government's decisions as a form of 'local participation'. According to Watts (2010), working in the same sites:

Villagers $[\cdots]$ have significantly less voice than people representing higher levels of governance. Local people and their aspirations must be included in any management or governance institution if landscape governance is to be equitable.

By including staff from the district in our team, we tried to develop a monitoring system not only relevant to village and kumban priorities, but also the district. This was also applicable when choosing NTFPs, and the way to report the results and recommendations for further action. The involvement of local people from each village in all steps of the monitoring system, from its design to testing, was also to ensure local relevance and participation.

Reasons for participating or not in monitoring activities

During the testing period we measured local participation and looked for the reasons why certain villages were more engaged in the process than others, but this was limited by the project's life, the impact of gold mining, and the understanding of the overall process (e.g. the issue of tax on NTFPs). Gold mining activities had a major impact on daily life in three of our pilot villages (i.e. Muangmuay, Vangmat, and Vangkham) and, by extension, on our activities and research results. A considerable number of villagers involved in gold mining stopped participating in the monitoring work.

Three of the six villages were showing promising signs in the utilization of the monitoring tool. Some villagers, individually or collectively, developed a sense of ownership of the tool and appreciated its benefits, not necessarily as a means of negotiation, but for themselves to visualize the changes affecting their forest resources. These three villages were located upstream from the gold extraction. Fish was still an important resource for them.

Participation was also influenced by the villagers' capacity for self-mobilization. Having meetings on a regular basis is necessary for sharing and discussing the monitoring results; this was something villagers were not necessarily used to.

Another issue affecting the willingness of local people to participate was tax. They were sometimes concerned that if they declared the real value of marketable NTFPs, they would have to pay more tax. These concerns were enhanced by the involvement of local authorities in the process. This is why, occasionally, they did not provide true amounts and 
did not attend meetings. To address this issue, the links between the different levels (village, kumban and district) need to be emphasized and strengthened, and the possible impacts of monitoring activities clarified.

Incentive for participating and local priorities

Collecting data on NTFP harvest is an investment in terms of time and effort, and without incentives, even the most relevant monitoring is unlikely to be sustained. Incentives could be, for example, better access to government programmes, services, and capacity building in terms of using the results as a powerful negotiating tool. We emphasised the latter during each of our meetings with villagers. We explained how to build an argument with or without the support of proven facts. For example, by using quantitative information on the cardamom harvest from the wild, during the previous few months, villagers were able to discuss with district officers whether the area designated in the land use plan for this NTFP collection was sufficient or not. They could also discuss whether the proposed management plans during PLUP for the area, and for the resource in question, were appropriate or not. However, the example of the gold mine shows the limitations of participatory approaches and of the level of empowerment they can provide to local communities. As far as incentives are concerned, local people's concerns in terms of land and natural resource management were small when compared to the bigger issues. This included the lack of power to prevent or control the private companies' activities and the short-term benefits when villagers were given permits for exploiting gold in the river within the concession area. But if properly embedded into official government policies, PLUP can include actual and potential drivers of change (e.g. agro-industry, mining) as one of the issues to be discussed and agreed upon between villagers and government organizations.

A system applicable to ongoing government policies

Monitoring, as part of PLUP, was first implemented in Muangmuay kumban at the time of our project. PLUP is important as it provides orientations regarding land management in the kumban for a period of 5 years.

Two of the PLUP monitoring objectives (MAF and NLMA 2009, 2010) are to:

Assess the impacts of PLUP on natural resource management at the village and village cluster levels.

And

Improve forest and agricultural land management used by communities at the village and village cluster levels.

Our monitoring system developed a regular and repetitive assessment of NTFP harvest, in order to understand the changes in the environment, based on the impact of decisions made during PLUP. Table 4 shows a potential monitoring system that provides information on the effectiveness of different land uses, based on relevant, selected indicators. If this suggestion is accepted, the monitoring system could link local people's priorities to major government decisions and policies. Participatory monitoring could be applied in each of the official zones proposed for PLUP. Even if some zones may need a non-participatory kind of monitoring, for example, GIS monitoring and biophysical monitoring in protected areas, participatory monitoring may still be complementary. 
The monitoring system proposed here links various types of activities to their effects. In some cases, we can distinguish between a minimal monitoring system, made of repeated, shared and discussed observations of changes among various social groups, and the optimal monitoring system providing facts and 'hard' data. A major part of our multistakeholder monitoring system was to recognize that changes in the landscape and people's livelihoods are occurring, and to look for 'more desirable' futures, acceptable to villagers and decision-makers (Belcher et al. 2013). With sufficient time secured and regular "interlevel" meetings, it could become the first step towards 'adaptive monitoring systems'.

Time for explaining, testing and refining the monitoring system

Because our project ran for only 2 years, we focused on a system development, rather than a full implementation of natural resource monitoring, hoping for a follow-up through future national or international development projects. This was barely enough time to familiarise the project staff with the concepts and to develop and test the monitoring approach. More time is needed to refine the approach based on the results from the test, and to work at its integration into PLUP. It is also necessary to follow the local pace, at the district level, which needs annual reporting on impacts of its policies and decisions. Of equal importance is the pace at the kumban and village levels, which follows different seasons. This would include seasons for NTFPs, rice harvest, and reporting to the district.

Projects, when using participatory monitoring, need to understand the economic context in which a target area evolves, and to include the short and medium-term variables affecting the area (e.g. seasonal activities and annual changes). Equally, projects need to be aware of and adapt to various threats and unexpected changes, such as gold mining, that can suddenly affect the system and compromise the accuracy of the results. Adaptive and progressive approaches need therefore to be developed, starting small on common concerns and building on the first experiences. For these reasons, short-term research and development projects can be effective in ensuring that monitoring is sustained only if they make the link to long-term processes and programs.

\section{Conclusion}

Participatory NTFP monitoring can work. It is potentially an important tool for multistakeholder decision-making, but both its limitations and potential for management need to be clearly identified. Our research shows that simple ways to monitor limited, but relevant, forest products require a sufficient time frame. It should also be noted that the integration of existing and possible future activities that enhance the local interest and sense of ownership are key to ensure participation and sustainability of the overall process.

Not a technical issue but needs time for full implementation

During the project implementation, we found that working with the villagers on specific resources (important economic NTFPs) is easy and sufficient to provide numbers that can be locally relevant and help with local decision-making in natural resource management. As we explained before, this requires following the local pace, villagers' agenda and seasonal duties, which all need time.

In order to be fully implemented, monitoring requires secured time. The time we had during our project was enough to develop an approach to identify the different issues to be 
included in a monitoring system (i.e. time, seasonal calendar, people's availability, necessity of a multi-stakeholder engagement, selection of simple but important NTFPs). The repetition of assessments and measurements, and data quality control needs regular visits to the monitored villages. In our case, the 2 year-duration of our research was not enough to achieve long-term impacts. It did not allow real testing. We were only able to test the monitoring system for 6 months, which did not cover a full season of NTFP collection. Unpredictable events were among the limitations we identified for full implementation of the monitoring system. We recommend at least two cycles of NTFP harvest (i.e. 2 years), which would allow comparison, to test the approach and learn from the results.

Integration into national policies (here PLUP) was in progress at the end of the project (Lestrelin et al. 2011, Bourgoin and Castella 2011, Bourgoin et al. 2012), but we lacked time to discuss with decision-makers ways the monitoring could be used to assess the impact of LUP and to scale up.

\section{Scaling up}

The monitoring system developed in Laos has the potential to address multi-stakeholders' concerns: villagers, including local elites, local authorities at the kumban and district levels, and organizations working on community development and conservation. Integrating these management practices into multi-level and multi-scale governance could support win-win solutions for both the villagers (data to negotiate) and the district authorities (data to deliver to the provincial level). If embedded in existing local governance and applied in key government policies, it could be used as a tool to empower local communities. This could be achieved by providing them with information on the effects of land management policies on forest resources and livelihoods. The different steps we propose could be applied easily to different situations elsewhere in the country. This could be with different ethnic groups, involving villages at different steps of rural transition, and different scales, from the village level to the village cluster and to the landscape. For the time being, we can only share the potential of this approach and call for more implementation trials before expanding it to different situations and provinces in the country.

Acknowledgments The authors thank the Viengkham community for their participation to their activities. They also thank Glen Mulcahy, Douglas Sheil and the anonymous reviewer for their valuable comments and editing, and Mohammad Agus Salim for designing the maps. They acknowledge the Swiss Agency for Development and Cooperation (SDC) and the European Commission for their financial support. This research was carried out by the Center for International Forestry Research (CIFOR), the Agricultural Research Center for International Development (CIRAD), as part of the CGIAR Research Program on Forests, Trees and Agroforestry, and the National Agricultural and Forestry Research Institute (NAFRI) in Lao PDR.

Open Access This article is distributed under the terms of the Creative Commons Attribution License which permits any use, distribution, and reproduction in any medium, provided the original author(s) and the source are credited.

\section{References}

Andrianandrasana HT, Randriamahefasoa J, Durbin J, Lewis RE, Ratsimbazafy JH (2005) Participatory ecological monitoring of the Alaotra wetlands in Madagascar. Biodivers Conserv 14:2757-2774 
Armitage DR, Plummer R, Berkes F, Arthur FI, Charles AT, Davidson-Hunt IJ, Diduck AP, Doubleday NC, Johnson DS, Marschke M, McConney P, Pinkerton EW, Wollenberg EV (2009) Adaptive co-management for social-ecological complexity. Front Ecol Environ 7:95-102

Baird IG (2010) Land, rubber and people: rapid agrarian changes and responses in southern Laos. J Lao Stud $1: 1-47$

Belcher B, Bastide F, Castella JC, Boissière M (2013) Development of a village-level livelihood monitoring tool: a case-study in Viengkham District, Lao PDR. Int Forest Rev 15(1):48-59

Berkes F, Folke C (1998) Linking social and ecological systems: management practices and social mechanisms for building resilience. Cambridge University Press, Cambridge

Berkes F, Colding J, Folke C (2000) Rediscovery of traditional ecological knowledge as adaptive management. Ecol Appl 10:1251-1262

Boucard A, Boissière M, Castella JC, Basuki I, Ponkphady S, Mouaxeng-cha K, Thephavanh M, Vongmany O (2010) Methodology of design of a participatory monitoring system for clusters of villages in Lao PDR. Technical Report, CIFOR and NAFRI

Bourgoin J, Castella JC (2011) "PLUP FICTION": landscape simulation for participatory land use planning in Northern Lao PDR. Mt Res Dev 31:78-88

Bourgoin J, Castella JC, Pullar D, Lestrelin G, Bouahom B (2012) Toward a land zoning negotiation support platform: "Tips and tricks" for participatory land use planning in Laos. Landsc Urban Plan 104:270-278

Chambers R (2006) Participatory mapping and geographic information systems: whose map? Who is empowered and who disempowered? Who gains and who loses? EJISDC 25:1-11

Chazee L (1999) The peoples of Laos, rural and ethnic diversities. White Lotus, Bangkok

CIFOR (2010) Building sustainable landscape management in the Lao PDR. Policy Brief, CIFOR and NAFRI

Colfer CJP (2007) Simple rules for catalyzing collective action in natural resource management contexts. CIFOR, Jakarta

Cundill G, Fabricius C (2009) Monitoring in adaptive co-management: toward a learning based approach. J Environ Manag 90:3205-3211

Danielsen F, Burgess ND, Balmford A (2005a) Monitoring matters: examining the potential of locally-based approaches. Biodivers Conserv 14:2507-2542

Danielsen F, Jensen AE, Alviola PA, Balete DS, Mendoza M, AnsonTagtag, Custodio C, Eenghoff M (2005b) Does monitoring matter? A quantitative assessment of management decisions from locallybased monitoring of protected areas. Biodivers Conserv 14:2633-2652

Danielsen F, Burgess ND, Balmford A, Donald PF, Funder M, Jones JPG, Alviola P, Balete DS, Blomley T, Brashares $\mathbf{J}$ et al (2008) Local participation in natural resource monitoring: a characterization of approaches. Conserv Biol 23(1):31-42

DeNeve KM, Heppner MJ (1997) Role play simulations: the assessment of an active learning technique and comparisons with traditional lectures. Innov High Educ 21:231-246

Evans KA, Guariguata MR (2007) A global review of participatory monitoring in tropical forest management. CIFOR, Bogor

Foppes J (2008) Knowledge capitalization: agriculture and forestry development at "Kum Ban" Village cluster level in Lao PDR. Technical report, LEAP and NAFES

Fraser EDG, Dougill AJ, Mabee WE, Reed M, McAlpine P (2006) Bottom up and top down: analysis of participatory processes for sustainability indicator identification as a pathway to community empowerment and sustainable environmental management. J Environ Manag 78:114-127

Garcia CA, Lescuyer G (2008) Monitoring, indicators and community based forest management in the tropics: pretexts or red herrings? Biodivers Conserv 17(6):1303-1317

Hargitai HI (2006) Planetary maps: visualization and nomenclature. Cartographica 41(2):150-164

Laumonier Y, Bourgeois R, Pfund J-L (2008) Accounting for the ecological dimension in participatory research and development: lessons learned from Indonesia and Madagascar. Ecol Soc 13:22

Lestrelin G, Bourgoin J, Bouahom B, Castella J-C (2011) Measuring participation: case studies on village land use planning in northern Lao PDR. Appl Geogr 31:950-958

MAF (2008) Ministerial direction of the Minister of Agriculture and Forestry on "establishing agriculture and forestry technical service center" MAF, Vientiane

MAF, NLMA (2009) Participatory Agriculture and Forest Land Use Planning at Village and Village Cluster Level. Report, Ministry of Agriculture and Forestry and National Land Management Authority

MAF, NLMA (2010) Participatory Agriculture and Forest Land Use Planning at Village and Village Cluster Level. Report, Ministry of Agriculture and Forestry and National Land Management Authority

NAFRI, NAFES, NUOL (2005) Improving livelihoods in the upland of the Lao PDR, Volume 1: Initiatives and approaches. National Agriculture and Forestry Research Institute, Vientiane 
NAFRI, NUOL, SNV (2007) Non-Timber Forest Products in the Lao PDR. A Manual of 100 Commercial and Traditional Products. The National Agriculture and Forestry Research Institute, Vientiane

Noss AJ, Oetting I, Cuéllar RL (2005) Hunter self-monitoring by the Isoseño-Guaraní in the Bolivian Chaco. Biodivers Conserv 14:2679-2693

Pfund J-L, Watts J, Boissière M, Boucard A, Bullock R, Ekadinata A, Dewi S, Feintrenie L, Levang P, Rantala $S$ et al (2011) Understanding and integrating local perceptions of trees and forests into incentives for sustainable landscape management. Environ Manag 48(2):334-349. doi:10.1007/ s00267-011-9689-1

Poulsen MK, Luanglath K (2005) Projects come, projects go: lessons from participatory monitoring in southern Laos. Biodivers Conserv 14:2591-2610

Prime Minister (2008) Supplement to the Prime Minister's order on establishing of development villages and village clusters. Vientiane

Rijsoort JV, Jinfeng Z (2005) Participatory resource monitoring as a means for promoting social change in Yunnan, China. Biodivers Conserv 14:2543-2573

Sheil D, Lawrence A (2004) Tropical biologists, local people and conservation: new opportunities for collaboration. Trends Ecol Evol 19:634-638

Sheil D, Puri RK, Basuki I, Heist MV, Wan M, Liswanti N, Rukmiyati, Sardjono MA, Samsoedin I, Sidiyasa $\mathrm{K}$ et al (2002) Exploring biological diversity, environment and local people's perspectives in forest landscapes methods for a multidisciplinary landscape assessment. Center for International Forestry Research, Bogor

Stringer LC, Dougill AJ, Fraser E, Hubacek K, Prell C, Reed MS (2006) Unpacking "participation" in the adaptive management of social-ecological systems: a critical review. Ecol Soc 11:39

UNODC (2005) Laos Opium Survey. Report, United Nations Office on Drugs and Crime

Watts J (2010) The governance of tropical landscapes. In: Colfer CJP, Pfund J-L (eds) Collaborative governance of tropical landscapes. Earthscan, London, pp 35-54

Watts JD, Vihemäki H, Boissière M, Rantala S (2010) Information flows, decision-making and social acceptability in displacement processes. In: Colfer CJP, Pfund J-L (eds) Collaborative governance of tropical landscapes. Earthscan, London, pp 79-106

Webber AD, Hill CM, Reynolds V (2007) Assessing the failure of a community-based human-wildlife conflict mitigation project in Budongo Forest Reserve, Uganda. Oryx 41:177-184

Weyerhaeuser HM, Bertomeu A, Wilkes, Mei Y (2010) Cross-border NTFP value chains Laos, China. Technical report, NAFRI and ICRAF http://www.nafri.org.la/document/URDP/documents/05_ Specialreports/09_Laos-China_NTFP.pdf. Accessed 22 Sep 2011

Widmann P, Baral HS, Easton M (2003) Nepal development of participatory biodiversity monitoring concept and methodology. Chria Forest Development Project PN 2001.2173.1, GOPA-AGEG, Bad Homburg

Yasue M, Kaufman L, Vincent ACJ (2010) Assessing ecological changes in and around marine reserves using community perceptions and biological surveys. Aquat Conserv Marine Freshwater Ecosyst 20:407-418 